\title{
The testis of the mice C57/BL6 offspring in adulthood have alterations due to maternal caffeine consumption ${ }^{1}$
}

\author{
Fernanda Silveira Cavalcante ${ }^{\mathrm{I}}$, Verônica Aiceles ${ }^{\mathrm{II}}$, Diana de Freitas Serapião Moraes ${ }^{\text {III }}$, Jorge Luiz Alves-Pereira ${ }^{\text {IV }}$, \\ Tatiane Silva Faria ${ }^{\mathrm{V}}$, Cristiane da Fonte Ramos ${ }^{\mathrm{VI}}$
}

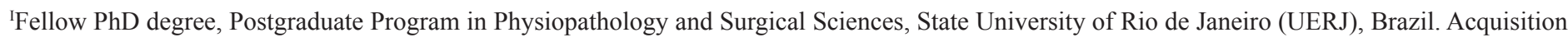
and interpretation of data; manuscript writing.

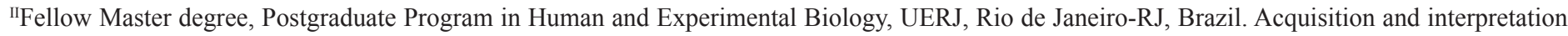
of data.

IIIMSc, Physiotherapist, State Department of Health, Rio de Janeiro, Brazil. Acquisition of data.

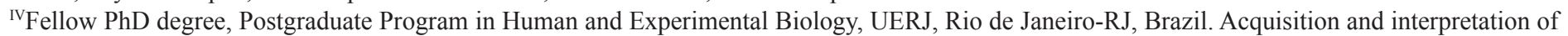
data.

${ }^{\mathrm{V}}$ Visiting Assistant Professor, Anatomy Department, UERJ, Rio de Janeiro-RJ, Brazil. Conception and design of the study, manuscript writing.

${ }^{\mathrm{VI}}$ Associate Professor, Anatomy Department, UERJ, Rio de Janeiro-RJ, Brazil. Conception and design of the study, manuscript writing, critical revision.

\section{ABSTRACT}

PURPOSE: To investigate the effects of the maternal caffeine consumption during pregnancy to adult male testis mice offspring.

METHODS: Twenty pregnant mice were divided into control group (c) and caffeine group (cf). dams received daily saline or $20 \mathrm{mg} / \mathrm{kg}$ of caffeine subcutaneously. Male offspring were monitored daily until $13^{\text {th }}$ week. The testis were used to evaluate both the proliferation (pcna) and apoptosis (bax); leptin receptor (ob-r); aromatase; follicle stimulating hormone (fshr), luteinizing hormone (lhr) and androgen receptors (ar); steroidogenic acute regulatory protein (star); vascular endothelial growth factor (vegf) and estrogen receptors (er $\alpha$ and er $\beta$ ) by western blotting. Serum concentrations of testosterone, estradiol and leptin were measured.

RESULTS: There was a significant reduction in food intake and the body mass gain $(p<0.05)$ in the $c f ; p c n a(p=0.01)$, fshr $(p=0.02)$, $\operatorname{star}(p=0.0007), \operatorname{vegf}(p=0.009), \operatorname{ar}(p=0.03)$ in the cf. while an increase were note in bax $(p=0.01), o b-r(p=0.02), 1 h r(p=0.04)$ and in the aromatase $(\mathrm{p}=0.03)$ in the cf. only er $\alpha$ and er $\beta$ were not changed by maternal caffeine. The serum testosterone levels in the $\mathrm{cf}$ offspring were $90 \%$ lower than in the coffspring ( $\mathrm{p}=0.04)$.

CONCLUSION: Maternal caffeine consumption has a role and alters the testis of the offspring in adulthood.

Key words: Caffeine. Fetal Development. Testis. Mice. 


\section{Introduction}

In recent years, concerns have been growing about the decrease in male reproductive health as found in declining semen quantity and quality in developing countries ${ }^{1}$. Literature reports an increasing risk of poor semen quality with increasing coffee consumption $^{2}$ and caffeine has been implicated in a number of epidemiologic studies as a risk factor for infertility, fetal loss, and fetal growth impairment ${ }^{3}$. However, a literature review of human studies from 2000 to 2009 reported no positive relationship between caffeine consumption and adverse effects on fertility ${ }^{4}$.

The majority of the world's population including pregnant women uses substantial amounts of caffeine on a regular basis ${ }^{5,6}$. The most commonly known sources of caffeine are coffee, cocoa beans, kola nuts, and tea leaves, but at least 63 plant species worldwide present compounds known as methylxanthines like caffeine (1, 3, 7-trimethylxanthine) $)^{7}$. Importantly, caffeine as a hydrophobic compound is able to pass through the placenta, reaching the fetus ${ }^{8}$. Caffeine elimination half-life increases in late gestation; and infants poorly metabolize caffeine until three months of age ${ }^{9}$. These observations give rise to the concept that the intake of caffeine during gestation represents a sort of fetal programming ${ }^{10}$.

Given the contradictory results on the reproductive effects of caffeine, the goal of the present study was to investigate the possible effects of the maternal caffeine consumption during pregnancy to adult male testis mice offspring.

\section{Methods}

The study was performed in accordance with the guidelines of the "Care Use of Laboratory Animals". The handles and experimental protocols were approved by the Animal Ethics Committee of the State University of Rio de Janeiro, Brazil (protocol 029/2012). All the animals were kept under standard conditions ( $12 \mathrm{~h}$ light/dark cycles, $21 \pm 2^{\circ} \mathrm{C}$, humidity $60 \pm 10 \%$ ) and had free access to water and standard rodent chow ${ }^{11}$.

Ten C57BL/6 females were mated with males and the day 1 of gestation was considered the day that the vaginal plug was found positive. Then, pregnant mice were transferred to individual cages and were randomly divided into two groups $(n=5$ each group): Control group (C) mothers received daily subcutaneous saline $0.9 \% \mathrm{NaCl}$, and Caffeine group (CF) mothers received daily $20 \mathrm{mg} / \mathrm{kg}$ of caffeine subcutaneously $(1 \mathrm{mg} / \mathrm{mL}$ in saline, SigmaAldrich Co., St. Louis, MO, USA), which mimetizes the dose of four to six cups of coffee per day in humans ${ }^{12}$. In both groups, the injections were made from the first day until the end of gestation.
Within $24 \mathrm{~h}$ of birth, excessive pups were removed so that only six pups were kept per dams to maximize lactation performance $^{13}$. The offspring of Control mothers were named as control (C), and the offspring from Caffeine mothers were named as caffeine $(\mathrm{CF})$. After weaning, one male per litter was randomly taken to form the experimental groups, based on their dams ( $n=5$ each group). They were housed until adulthood (three months old) with free access to food and water. Each mouse was weighed weekly during the experimental period, and food intake was measured daily.

All animals were killed with an overdose of pentobarbital (150 mg/kg), blood was collected by cardiac puncture and serum stored at $-20^{\circ} \mathrm{C}$ until further evaluation of hormone concentrations. The left testis were excised, dissected, weighted then embedded in Paraplast (Sigma-Aldrich Co., St. Louis, MO, USA), sectioned at $5 \mu \mathrm{m}$ thickness and processed by routine histological analyses. The right testis were stored at $-80^{\circ} \mathrm{C}$ for further analysis of the protein expression by Western blot. In addition, the left tibial length was measured to correct the body mass and testis mass in the animals ${ }^{14}$.

Deparaffined sections of the testis were used to evaluate both the proliferation and apoptosis by immunohistochemistry. Briefly, the sections were incubated for two hours at $37^{\circ} \mathrm{C}$ with Proliferating Cell Nuclear Antigen (PCNA, Life Technologies, CA, USA), diluted 1:200 in PBS with 1\% BSA. Afterwards, sections were washed in PBS and incubated at room temperature with biotinylated secondary antibody and streptavidin-peroxidase conjugate (Histostain-Plus Kit, Invitrogen, CA, USA). The sections were then revealed with liquid diaminobenzidine (HistostainPlus Kit, Invitrogen, CA, USA), and then counterstained with hematoxylin. The negative controls were processed by replacing the primary antibody with PBS and no indication of staining was observed. Apoptosis was detected in situ with the Apoptag plus peroxidase kit (Apoptosis Detection Kit, Chemicon Int, Millipore, Billerica, MA).

The serum concentrations of testosterone and estradiol were measured by chemiluminescence (Roche). The limit of detection was $0.025 \mathrm{ng} / \mathrm{mL}$ for testosterone and $5.0 \mathrm{pg} / \mathrm{mL}$ for estradiol. Leptin was measured by Elisa (Millipore) and the limit of detection was $0.08 \mathrm{ng} / \mathrm{mL}$.

For protein evaluation by Western blot, testis was homogenized in $250 \mu \mathrm{L}$ TEG buffer (50 mMTris, pH 7.4, $1.5 \mathrm{mM}$ Methylenediaminetetra-acetic acid, $50 \mathrm{mM} \mathrm{NaCl}$, glycerol 10\%, 5 $\mathrm{mM}$ dithiothreitol, $1 \mu \mathrm{g} / \mathrm{mL}$ of protease inhibitor cocktail - SigmaAldrich, MO,USA). The tissue homogenates were centrifuged twice at $3.000 \mathrm{xg}$ for $20 \mathrm{~min}$ at $4^{\circ} \mathrm{C}$, and the supernatants were used for analysis. The antibodies used are described in Table 1. 
TABLE 1. Information regarding the antibodies used in the western blot technique. The letters and numbers in parenthesis correspond to the catalog number of the antibody.

\begin{tabular}{ccc}
\hline Primary antibody & $\begin{array}{c}\text { Dilution } \\
\text { factor }\end{array}$ & Manufacturer \\
\hline AR (5c-816) & $1: 250$ & Santa Cruz, CA, USA \\
Aromatasc (ab-69653) & $1: 500$ & Abcam, MA, USA \\
$\beta$-actin (sc-81178) & $1: 1000$ & Santa Cruz, CA, USA \\
Bax (sc-493) & $1: 1000$ & Santa Cruz, CA, USA \\
ER- $\alpha$ (sc-8002) & $1: 250$ & Santa Cruz, CA, USA \\
ER- $\beta$ (sc-53494) & $1: 500$ & Santa Cruz, CA, USA \\
FSHR (sc-7798) & $1: 500$ & Santa Cruz, CA, USA \\
LHR (sc-25828) & $1: 200$ & Santa Cruz, CA, USA \\
Ob-R (sc-1834) & $1: 500$ & Santa Cruz, CA, USA \\
PCNA (18-0110) & $1: 500$ & Life Technologies, CA, \\
StAR (ab-58013) & $1: 250$ & Abcam, MA, USA \\
VEGF (sc 7269) & $1: 500$ & Santa Cruz, CA, USA \\
Secondary antibody & & \\
Anti-goat (sc-2768) & $1: 1000$ & Santa Cruz, CA, USA \\
Anti-mouse (sc-2005) & $1: 2000$ & Santa Cruz, CA, USA \\
Anti-rabbit (12-348) & $1: 2000$ & Millipore, Billerica, MA \\
\hline
\end{tabular}

The data are shown as mean and standard error of the mean. The differences between the groups were analyzed with the unpaired Student's t test with Welch's correction as needed. $\mathrm{p}<0.05$ was considered statistically significant.

\section{Results}

Maternal caffeine administration during pregnancy resulted in a significant reduction in food intake from the 11th week, and body mass from the 6th week until sacrifice (Figure 1). At the end of the experiment, the testis mass/tibial length ratio was reduced by $19 \%$ in the CF group compared to the C group (C group, $7.8 \pm 0.3 \% \mathrm{~g} / \mathrm{cm}$; CF group, $6.3 \pm 0.2 \% \mathrm{~g} / \mathrm{cm}$; $\mathrm{p}<0.002$ ).
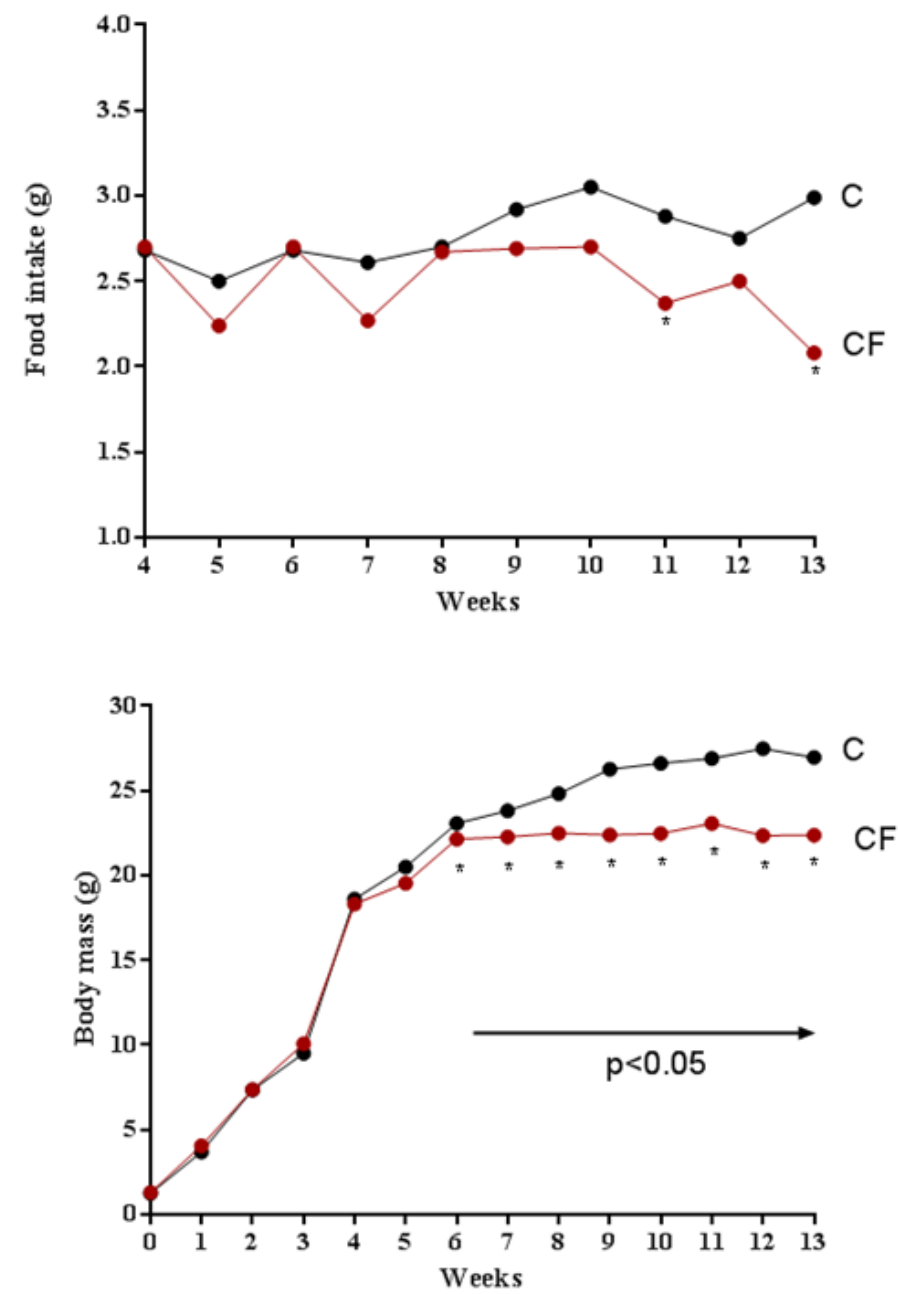

FIGURE 1 - Food intake (A) and body mass (B) of the offspring whose mothers received $0.9 \% \mathrm{NaCl}(\mathbf{C})$ or caffeine (CF $; 20 \mathrm{mg} / \mathrm{kg} /$ day) during pregnancy. Data are expressed as means \pm S.E.M. of five animals of 90 days of age. The symbol * means statistical significance. 
The caffeine administration during pregnancy changed the expression of several important proteins in the testis. There was an increase in the protein expression of leptin receptor $(\mathrm{Ob}-\mathrm{R})$, in the luteinizing hormone receptor (LHR) and in the aromatase. There was a decrease in the follicle stimulating hormone receptor (FSHR), in the steroidogenic acute regulatory protein (StAR), in the vascular endothelial growth factor (VEGF), and in the androgen receptor (AR). Only estrogen receptors (ER $\alpha$ and $E R \beta)$ were not changed by maternal caffeine administration (Figure 2).

\section{A}
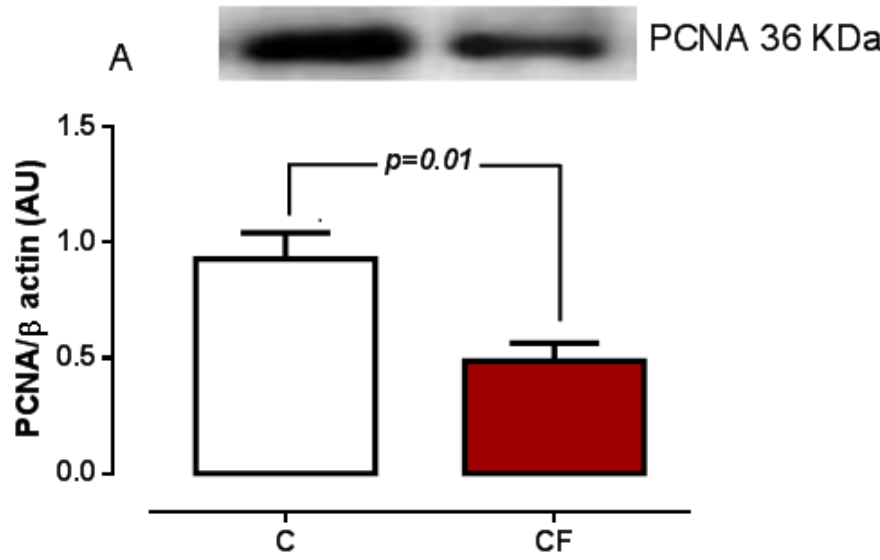

B

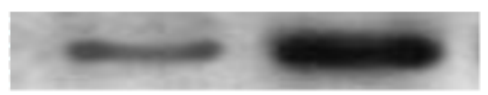

BAX $23 \mathrm{KDa}$

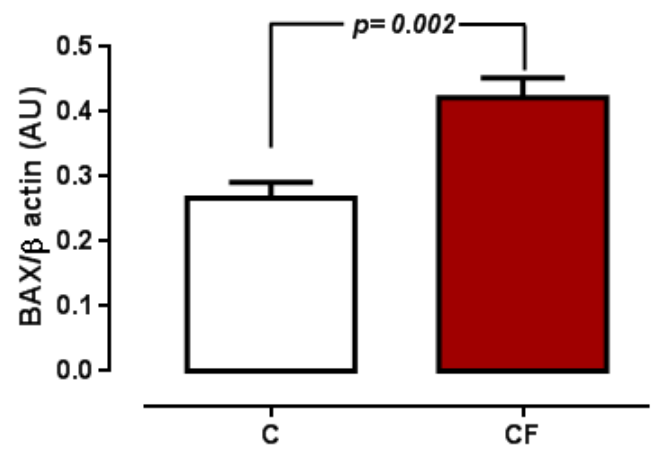

FIGURE 2 - Western blot analysis of AR (A), FSHR (B), LHR (C), StAR (D), Ob-R (E), VEGF (F), Aromatase $(\mathbf{G}), \operatorname{ER} \alpha(\mathbf{H})$ and ER $\beta(\mathbf{I})$ of the offspring's testes whose mothers received $0.9 \% \mathrm{NaCl}(\mathbf{C})$ or caffeine (CF; $20 \mathrm{mg} / \mathrm{kg} /$ day) during pregnancy.
Sixty micrograms of total protein were loaded in each lane.

Data are expressed as means \pm S.E.M. of five animals of 90 days of age. $\mathrm{AR}=$ androgen receptor, $\mathrm{FSHR}=$ follicle stimulating hormone receptor, $\mathrm{LHR}=$ luteinizing hormone receptor, $\mathrm{StAR}=$ steroidogenic acute regulatory protein, $\mathrm{Ob}-\mathrm{R}=$ leptin receptor, $\mathrm{VEGF}=$ vascular endothelial growth factor, $\mathrm{AR}=$ androgen receptor, $\mathrm{ER} \alpha$ and $E R \beta=$ estrogen receptors. $\beta$ actin was used as an internal control.

In addition, there was a significant decrease in the PCNA expression, and an increase in the $\mathrm{Bcl}-2$ associated $\mathrm{X}$ protein (BAX) expression in the CF group (Figure 3).

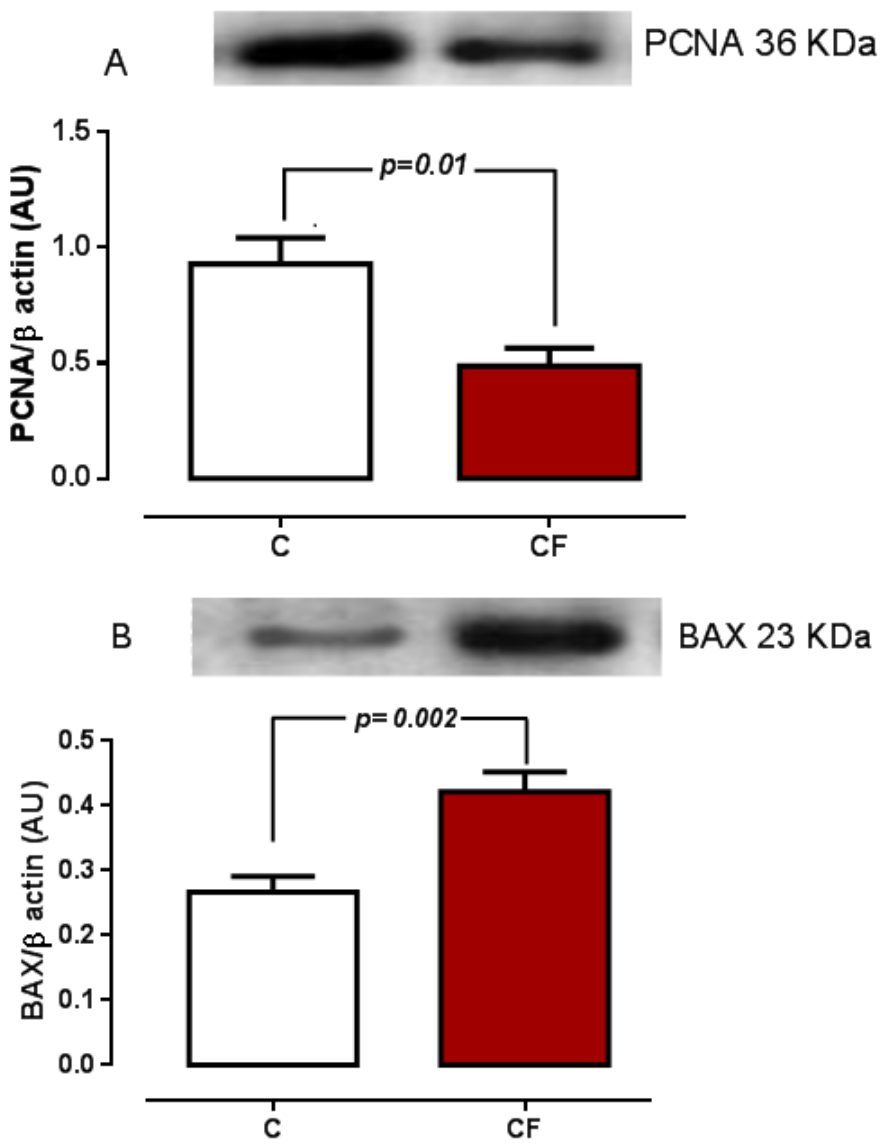

FIGURE 3 - Western blot analysis of PCNA (A) and BAX (B) of the offspring's testes whose mothers received $0.9 \% \mathrm{NaCl}(\mathbf{C})$ or caffeine (CF; $20 \mathrm{mg} / \mathrm{kg} /$ day) during pregnancy. Sixty micrograms of total protein were loaded in each lane. Data are expressed as means \pm S.E.M. of five animals of 90 days of age. PCNA= proliferating cell nuclear antigen, $\mathrm{BAX}=\mathrm{Bcl}-2-$ associated $\mathrm{X}$ protein. $\beta$ actin was used as an internal control. 
Proliferation was more evident in the germinal epithelium near the basal membrane, while the apoptosis seemed to affect the entire seminiferous epithelium of the offspring whose dams were submitted to caffeine administration during pregnancy (Figure 4).
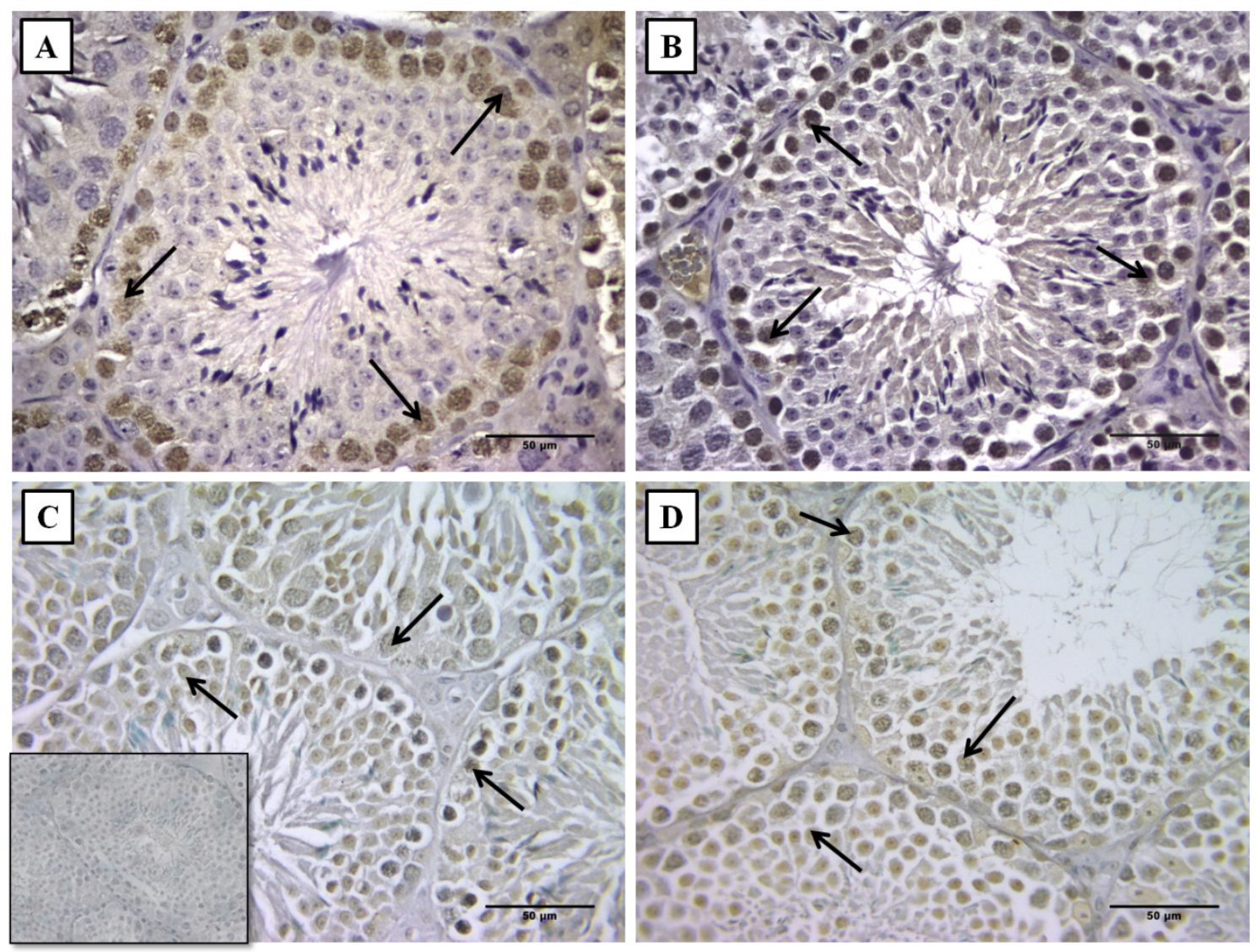

FIGURE 4 - Photomicrograph of immunohistochemistry for proliferating cell nuclear antigen $(\mathbf{A}, \mathbf{B})$ and apoptosis $(\mathbf{C , D})$ in the offspring's testes whose mothers received $0.9 \% \mathrm{NaCl}$-control group or caffeine, $20 \mathrm{mg} / \mathrm{kg} /$ day during pregnancy. Arrows show positive stain in the germinal epithelium. Note the difference in the number of stained cells between both groups (insert - negative control). 
The serum testosterone levels in the $\mathrm{CF}$ offspring were $90 \%$ lower than in the $\mathrm{C}$ offspring $(\mathrm{p}=0.04)$. However, the statistical analysis was not able to detect a significant difference concerning the serum leptin and serum estradiol (Figure 5).

\section{A}

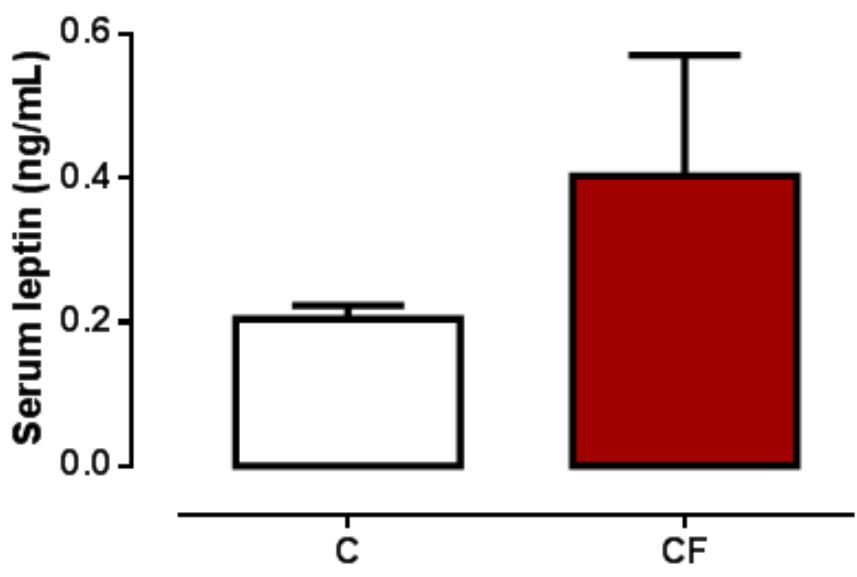

B

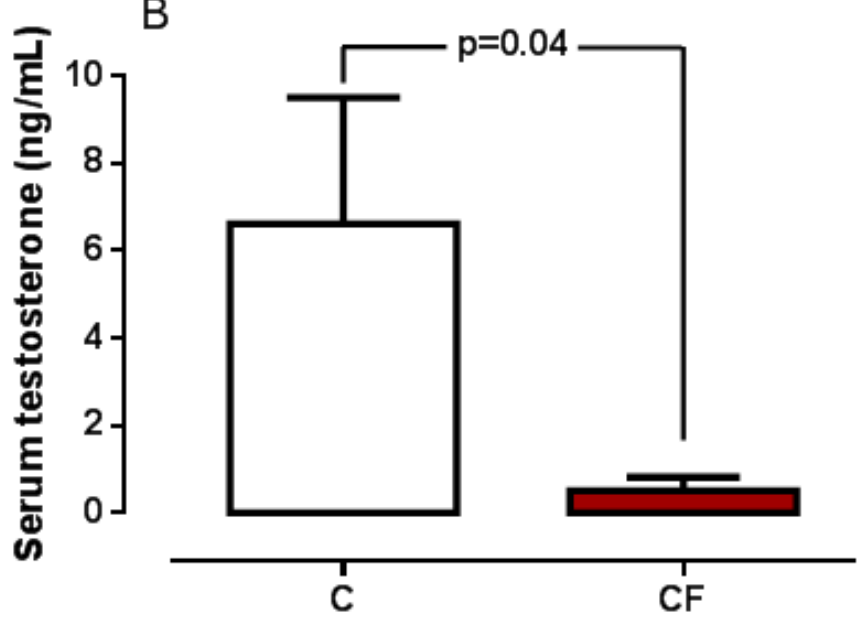

C

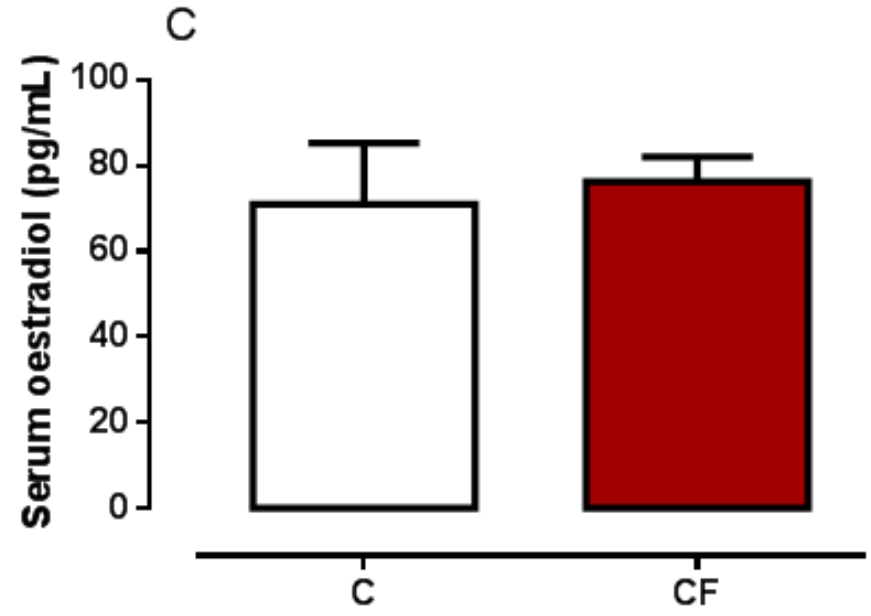

FIGURE 5 - Serum concentration of leptin (A), testosterone (B) and estradiol $(\mathbf{C})$ of the offspring whose mothers received $0.9 \% \mathrm{NaCl}(\mathbf{C})$ or caffeine (CF; $20 \mathrm{mg} / \mathrm{kg} /$ day) during pregnancy. Data are expressed as means \pm S.E.M. of five animals of 90 days of age.

\section{Discussion}

In the present study, maternal caffeine consumption during pregnancy had an impact on the mice offspring. No significant difference was observed in the body mass of the pups in the birthday. The consumption of caffeine by mothers during gestation has been associated with a low body mass of the pups at birth, or caused no alteration in the body mass of pups ${ }^{15}$. In addition, present results reinforce the hypothesis that caffeine has anorectic effects by promoting satiety and reducing body mass gain in the offspring ${ }^{16}$, since the caffeine-treated group presented a reduction in the food consumption and the body mass gain.

The adequate bioavailability of testosterone plays a role in the structural and functional integrity of the reproductive organs ${ }^{17}$. In the present study, serum testosterone in the $\mathrm{CF}$ offspring was much lower than in the $\mathrm{C}$ offspring but, probably due to the small sample size and the variability of the results, bothe the serum leptin and estradiol have no difference between the groups. Leptin is involved in the reproductive function regulation, it decreases the expression of several upstream elements in the steroidogenic pathway, and inhibits the testicular steroidogenesis ${ }^{18}$.

The CF offspring presented a decreased expression of the steroidogenic acute regulatory protein that is a limiting factor in the steroidogenic pathway and could explain the low levels of serum testosterone. These animals also presented high leptin levels and an increase of the $\mathrm{Ob}-\mathrm{R}$ expression in the testis, possibly increasing the testis response to leptin what would result in a decrease in testosterone serum biosynthesis. Another possibility is the fact that leptin is known to stimulate the aromatase enzyme ${ }^{19}$. Our results show that this protein expression was increased by maternal caffeine administration reinforcing a direct effect of the hormone in the testis. This increment in the aromatase expression could have been responsible to maintain estradiol serum levels in a normal range.

Leptin receptors expression in testis is under a negative control of gonadotropins and leptin itself $f^{18}$. However this autoregulation seems to be tissue specific since in the prostate leptin increases the expression of Ob- $\mathrm{R}^{19}$. In the present study, the maternal caffeine intake disrupt the autoregulation process since the $\mathrm{CF}$ offspring presented high levels of serum leptin and a concomitant increase in the leptin receptor expression. Therefore, we could speculate that caffeine consumption during pregnancy programmed this tissue by increasing the expression of leptin receptors.

Both hormones testosterone and estradiol are known to autoregulate their receptors. In spite of having no reasonable explanation, caffeine did not change this process; low testosterone levels could have been responsible for the decrease observed in the 
androgen receptor expression, while estrogen receptors alpha and beta were unchanged in response to unchanged estradiol serum levels.

The testis response to gonadotropins was evaluated by the analysis of the gonadotropins receptor expressions. The CF offspring presented an increase in LHR expression and a decrease in FSHR expression that could be due to the testis programming by caffeine consumption during pregnancy. The increase in LHR expression could be the compensatory response of the testis in attempting to the increase testosterone biosynthesis. The caffeine treatment during gestation and lactation periods is known to decrease sperm density, percent of motile and morphologically normal sperm and sperm production in offspring at adulthood ${ }^{2}$. We hypothesize that the reduction in testis response to FSH could be responsible for the expected sperm alterations described after caffeine consumption. The present findings demonstrated a decreased proliferation (measured by PCNA) and an increased apoptosis in the seminiferous tubule of the CF offspring. Also, while proliferation was more evident in the germinal epithelium near the basal membrane, apoptosis seems to affect the entire seminiferous epithelium what could contribute to reduce the sperm recently formed. A reduction in blood and nutrient supply could be another factor to disrupt testis function and affects the sperm. We have found a reduced expression of VEGF in the CF offspring what is in agreement with past results showing that angiogenesis is reduced by drinking tea ${ }^{20}$.

More studies concerning the offspring's quality of spermatozoa are necessary to observe the maternal caffeine consumption in association with a possible disturbance of the offspring fertility.

\section{Conclusions}

The maternal caffeine consumption has a role and alters the testis of the offspring in adulthood. Besides, the results indicate that gestation is a sensitive period for induction of permanent adverse effects of caffeine on the offspring testis.

\section{References}

1. Olesen IA, Sonne SB, Hoei-Hansen CE, Rajpert-De Meyts E, Skakkebaek NE. Environment, testicular dysgenesis and carcinoma in situ testis. Best Pract Res Clin Endocrinol Metab. 2007; 21: 462-78.

2. Parazzini F, Marchini M, Tozzi L, Mezzopane R, Fedele L. Risk factors for unexplained dyspermia in infertile men: a case-control study. Arch Androl. 1993;31:105-13.

3. Fenster L, Eskenazi B, Windham GC, Swan SH. Caffeine consumption during pregnancy and fetal growth. Am J Public Health. 1991;81:458-61.
4. Peck JD, Leviton A, Cowan LD. A review of the epidemiologic evidence concerning the reproductive health effects of caffeine consumption: a 2000-2009 update. Food Chem Toxicol. 2010;48:2549-76.

5. Heck CI, de Mejia EG. Yerba Mate Tea (Ilex paraguariensis): a comprehensive review on chemistry, health implications, and technological considerations. J Food Sci. 2007;72:R138-51.

6. Greenwood DC, Alwan N, Boylan S, Cade JE, Charvill J, Chipps KC, Cooke MS, Dolby VA, Hay AW, Kassam S, Kirk SF, Konje JC, Potdar N, Shires S, Simpson N, Taub N, Thomas JD, Walker J, White KL, Wild CP. Caffeine intake during pregnancy, late miscarriage and stillbirth. Eur J Epidemiol. 2010;25:275-80.

7. Barone JJ, Roberts HR. Caffeine consumption. Food Chem Toxicol. 1996;34:119-29.

8. Kirkinen P, Jouppila P, Koivula A, Vuori J, Puukka M. The effect of caffeine on placental and fetal blood flow in human pregnancy. Am J Obstet Gynecol. 1983;147:939-42.

9. Aldridge A, Bailey J, Neims AH. The disposition of caffeine during and after pregnancy. Semin Perinatol. 1981;5:310-4.

10. Wendler CC, Busovsky-McNeal M, Ghatpande S, Kalinowski A, Russell KS, Rivkees SA. Embryonic caffeine exposure induces adverse effects in adulthood. FASEB J. 2009;23:1272-8.

11. Reeves PG, Nielsen FH, Fahey GC Jr. AIN-93 purified diets for laboratory rodents: final report of the American Institute of Nutrition ad hoc writing committee on the reformulation of the AIN-76A rodent diet. J Nutr. 1993;123:1939-51.

12. Fredholm BB, Battig K, Holmen J, Nehlig A, Zvartau EE. Actions of caffeine in the brain with special reference to factors that contribute to its widespread use. Pharmacol Rev. 1999;51:83-133.

13. Fischbeck KL, Rasmussen KM. Effect of repeated reproductive cycles on maternal nutritional status, lactational performance and litter growth in ad libitum-fed and chronically food-restricted rats. J Nutr. 1987;117:1967-75.

14. Yin FC, Spurgeon HA, Rakusan K, Weisfeldt ML, Lakatta EG. Use of tibial length to quantify cardiac hypertrophy: application in the aging rat. Am J Physiol. 1982;243:H941-7.

15. Soellner DE, Grandys T, Nunez JL. Chronic prenatal caffeine exposure impairs novel object recognition and radial arm maze behaviors in adult rats. Behav Brain Res. 2009;205:191-9.

16. Serapiao-Moraes DF, Souza-Mello V, Aguila MB, Mandarim-deLacerda CA, Faria TS. Maternal caffeine administration leads to adverse effects on adult mice offspring. Eur J Nutr. 2013. [Epub ahead of print]

17. Recabarren MP, Rojas-Garcia PP, Einspanier R, Padmanabhan V, Sir-Petermann T, Recabarren SE. Pituitary and testis responsiveness of young male sheep exposed to testosterone excess during fetal development. Reproduction. 2013;145:567-76.

18. Tena-Sempere M, Barreiro ML. Leptin in male reproduction: the testis paradigm. Mol Cell Endocrinol. 2002;188:9-13.

19. Alves-Pereira JL, Colli S, Marques DS, Sampaio FJ, Ramos CF. Molecular and morphometric analysis of the rat ventral prostate injected with leptin. Regul Pept. 2012;176:6-12.

20. Cao Y, Cao R. Angiogenesis inhibited by drinking tea. Nature. 1999;398(6726):381.

\section{Acknowledgement}

To Prof. Carlos Alberto Mandarim-de-Lacerda for their technical revision, PhD, Full Professor, Anatomy Department, UERJ. 


\section{Correspondence:}

Fernanda Silveira Cavalcante

Laboratório de Morfometria, Metabolismo e Doenças Cardiovasculares

Instituto de Biologia, UERJ

Avenida 28 de Setembro, 87, fundos

20551-030 Rio de Janeiro - RJ Brasil

fefycavalcante@gmail.com

fefy_cavalcante@hotmail.com

Received: Sept 10, 2013

Review: Nov 12, 2013

Accepted: Dec 11, 2013

Conflict of interest: none

Financial sources: National Council of Scientific and Technological

Development (CNPq) and Rio de Janeiro Research Foundation (FAPERJ)

${ }^{1}$ Research performed at Laboratory of Morphometry, Metabolism and Cardiovascular Diseases, Biomedical Center, Institute of Biology, State University of Rio de Janeiro (UERJ), Brazil. Part of PhD degree thesis, Postgraduate Program in Physiopathology and Surgical Sciences, UERJ. Tutor: Cristiane da Fonte Ramos. 